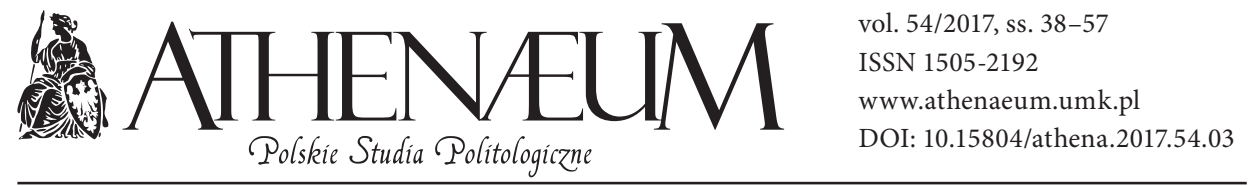

\title{
SZANGHAJSKA ORGANIZACJA WSPÓŁPRACY JAKO JEDNA Z FORM WIELOPŁASZCZYZNOWEJ WSPÓłPRACY ROSJI I CHIŃSKIEJ REPUBLIKI LUDOWEJ
}

\author{
SHANGHAI COOPERATION ORGANISATION AS A FORM \\ OF MULTIDIMENSIONAL SINO-RUSSIAN COOPERATION
}

\author{
Anna Kobierecka*
}

\begin{abstract}
ABSTRAKT
Upadek świata dwubiegunowego może zostać uznany za nowe otwarcie w stosunkach chińsko-rosyjskich. Sytuacja międzynarodowa na początku lat 90. umożliwiła odnowienie i normalizację stosunków politycznych między tymi państwami oraz zapoczątkowanie współpracy na kilku płaszczyznach. Rozwijanie kontaktów zarówno politycznych, jak i gospodarczych okazało się być procesem długotrwałym, warunkowanym przez liczne wewnętrzne i zewnętrzne czynniki. Celem artykułu jest analiza ewoucji wzajemnych relacji, motywacji działania, źródeł współpracy oraz jej znaczenia. Biorąc pod uwagę rosnące strategiczne znaczenie regionu eurazjatyckiego, szczególnym aspektem w kontekście współpracy Federacji Rosyjskiej i Chińskiej Republiki Ludowej jest jej istota dla bezpieczeństwa międzynarodowego. Przeprowadzana analiza będzie uwzględniała zwłaszcza współpracę rozwijaną z wykorzystaniem Szanghajskiej Organizacji Współpracy.
\end{abstract}

The fall of the bipolar world can be perceived as a new opening in Sino-Russian mutual relations. International reality at the beginning of the $1990^{\text {s }}$ enabled renewal and normalization of political relations between them and an establishment of broader cooperation in several areas. The process of widening their contacts, both political and economic, can be perceived as long-lasting and determined by many internal and external conditions. The aim of this article is to analyze the evolution of mutual relations, motivation, reasons and roots of such cooperation as well as its sense. The most significant aspect is the meaning of Sino-Russian cooperation, especially in the field of Shanghai Cooperation Organization, which in many aspects can be perceived as a threat to international security, mostly due to strategic significance of Eurasian region.

* Uniwersytet Łódzki, Instytut Studiów Politologicznych. 
Słowa kluczowe: Rosja, Chińska Republika Ludowa, Szanghajska Organizacja Współpracy, kooperacja rosyjsko-chińska
Keywords: Russia, People's Republic of China, Shanghai Cooperation Organization, SinoRussian cooperation

Po rozpadzie Związku Radzieckiego zakończony został wieloletni okres zimnowojennych antagonizmów w stosunkach międzynarodowych. Wraz z upadkiem świata dwubiegunowego pojawiła się nowa przestrzeń i nowe możliwości współpracy na obszarze azjatyckim. Na kontynencie tym najistotniejszymi graczami, mimo upadku Związku Radzieckiego, nadal pozostawała Federacja Rosyjska oraz Chińska Republika Ludowa, która dynamicznie rozwijała się pod kątem gospodarczym. Państwa te mimo dawnych antagonizmów oraz licznych konfliktów stanęły wobec nowej sytuacji międzynarodowej, w której nawiązanie współpracy mogłoby dać im nowe możliwości oraz wzmocnić ich pozycję na arenie międzynarodowej. Nowe otwarcie, jakim był upadek Związku Radzieckiego, we wzajemnych relacjach tych państw nie od razu zostało wykorzystane, jednak z czasem kooperacja zaczęła przybierać na sile, a wzajemne stosunki ulegać znaczącym przeobrażeniom.

Współpraca rosyjsko-chińska przybierała różnorodne formy. Począwszy od kontaktów dwustronnych i współpracy w zakresie handlu czy energetyki, aż do podjęcia działań w ramach Szanghajskiej Piątki, wspólnie z Kazachstanem, Kirgistanem i Tadżykistanem, a następnie w ramach Szanghajskiej Organizacji Współpracy. W niniejszym artykule podjęta zostanie próba weryfikacji hipotezy dotyczącej pragmatycznego charakteru współpracy rosyjsko-chińskiej, której podstawą jest realna ocena zysków i strat. Druga z hipotez zakłada, iż Szanghajska Organizacja Współpracy jest areną konfrontacji zarówno wspólnych interesów, jak i rywalizacji jej dwóch najsilniejszych członków, co widać na wszystkich płaszczyznach, na jakich odbywa się współpraca. Analizie poddane zostały zatem źródła i przyczyny współpracy rosyjsko-chińskiej - jakie czynniki wpłynęły na ponowne zbliżenie Rosji i Chin oraz jaki charakter ma ich współpraca. Wreszcie poruszona została problematyka współpracy militarnej w ramach SOW oraz jej możliwej dalszej ewolucji. W przygotowaniu artykułu zastosowanie znalazła w szczególności metoda porównawcza. Analizie poddane zostały czynniki kształtujące politykę zarówno Rosji, jak i Chińskiej Republiki Ludowej. Na tej podstawie możliwe było wskazanie elementów zbieżnych, będących czynnikami zbliżającymi oba państwa do siebie i motywujące je do podejmowania działań kooperacyjnych na różnych płaszczyznach. 


\section{OD KONFLIKTU DO WSPÓŁPRACY}

Historia wspólnych relacji rosyjsko-chińskich sięga blisko czterech wieków, a ich dynamika dyktowana była początkowo rozwojem regionalnych kontaktów przygranicznych. Już w 1689 r. podpisano pierwsze porozumienie regulujące granice między oboma państwami (Pietrasiak, Dacyszen, 2012). Istotnym utrudnieniem we współczesnych relacjach Związku Radzieckiego i Chińskiej Republiki Ludowej był fakt, iż oba państwa były państwami komunistycznymi, przy czym Związek Radziecki uzurpował sobie rolę nadrzędną i zwierzchnią względem tych, które również przyjęły komunistyczny system polityczny. Bolszewicy po rewolucji w 1917 r. zadbali o bliskie relacje zarówno z Kuomintangiem, jak i Chińską Partią Komunistyczną, gwarantując sobie tym samym wpływy na politykę wewnętrzną w tym państwie (Kaczmarski, 2015). O ile obszar Europy Środkowo-Wschodniej zdołano sobie finalnie podporządkować, o tyle Chińska Republika Ludowa z czasem zaczęła wykazywać własne ambicje i nie godziła się na dominację radziecką.

Jeszcze w okresie powojennym, gdy w Chinach władzę przejęła partia komunistyczna, bliskie relacje sojusznicze ze Związkiem Radzieckim nadal były rozwijane i pielęgnowane. Jednak z czasem wyraźne dążenie ZSRR do dominacji nad Chińską Republiką Ludową zaczęło być negatywnie odbierane i kontestowane w „państwie środka”. Szansą na przeciwstawienie się Komunistycznej Partii Związku Radzieckiego okazał się XX Zjazd KPZR w 1956 r. W referacie wygłoszonym podczas Zjazdu Nikita Chruszczow poddał krytyce wcześniejszą politykę Józefa Stalina, z którą nie zgodzili się Chińczycy (Roszkowski, 2005). Kolejny etap w pogarszających się relacjach wzajemnych miał miejsce w 1958 r., gdy Chińczycy przedstawili własny program udoskonaleń systemowo-gospodarczych pod hasłem „wielkiego skoku naprzód”. Była to inicjatywa jednoznacznie konkurencyjna wobec podobnych programów realizowanych w Związku Radzieckim (Kowalski, 2012, Kobierecki, 2013). Na początku lat 70. wzajemne relacje wkroczyły już w etap jawnej wrogości i wzajemnej niechęci. Izolacja ChRL pogłębiała się dodatkowo poprzez zainicjowaną rewolucję kulturalną, mającą na celu wyeliminowanie politycznych wrogów Mao Zedonga (Lawrance, 1998).

Aż do upadku Związku Radzieckiego stosunki z Chińską Republiką Ludową mogły być określane jako nieprzyjazne. Pozycja ZSRR nadal pozostawała zdecydowanie silniejsza względem chińskiego konkurenta, biorąc pod uwagę ścisłe relacje z Koreą Północną, Mongolią i Wietnamem oraz okupację Afganistanu (zob. Roberts, 2003, Kakar, 1995). Sytuacja zaczęła ulegać zmianie po upadku 
ZSRR, choć nie były to przemiany nagłe, a zbliżenie obu państw możliwe było dopiero po kilku latach od upadku świata dwubiegunowego. Spowodowane było to kilkoma czynnikami. Chiny po masakrze na placu Tienanmen w czerwcu 1989 r. stały się państwem izolowanym na arenie międzynarodowej.Z kolei Rosja pod przewodnictwem Borysa Jelcyna postrzegana była pozytywnie. Przemiany zachodzące w tym państwie sugerowały zbliżanie się Rosji w stronę Zachodu oraz powodowały, iż stawała się ona atrakcyjnym potencjalnym partnerem strategicznym dla Stanów Zjednoczonych. Jednak w efekcie końcowym próby reform w Rosji nie powiodły się, natomiast Chiny znalazły dla siebie własną drogę, wchodząc w etap szybkich przemian i dynamicznego rozwoju gospodarczego (Kaczmarski, 2015). Wzrastająca siła, potencjał i znaczenie Chińskiej Republiki Ludowej razem z nieskutecznymi próbami przeprowadzenia przemian wewnętrznych w Federacji Rosyjskiej i nieudaną próbą zbliżenia się do struktur zachodnich spowodowały, iż Rosja w swojej polityce zagranicznej zaczęła kierować się na Wschód, dostrzegając w Chinach realnego konkurenta w staraniach o dominowanie na obszarze azjatyckim. Istotne było również dążenie Federacji Rosyjskiej do odbudowy dawnej, radzieckiej strefy wpływów. Na tej płaszczyźnie wyraźnie dostrzegano zagrożenie ze strony Chińskiej Republiki Ludowej, która posiadała odpowiedni potencjał, możliwości i powoli rodzące się ambicje poszerzania swoich wpływów na kontynencie azjatyckim. Wobec osłabienia Rosji oraz jeszcze niewystarczającej potęgi Chin, a także chęci zapewnienia równowagi i stabilizacji na kontynencie, korzystniejsze wydawało się podjęcie współpracy niż otwartej konfrontacji i wyścigu o dominację.

Bezpośrednio po upadku ZSRR rozpoczęto starania zmierzające do nawiązania współpracy rosyjsko-chińskiej. W pierwotnej fazie celem nawiązanych kontaktów było unormowanie kwestii granic i wynikłych na tym polu konfliktów. W dalszej kolejności stworzenie struktur współpracy miało zapewnić tym państwom miejsce w nowych, unipolarnych realiach stosunków międzynarodowych i jednocześnie równoważyć rosnące w siłę państwa europejskie. Wydaje się zatem, iż ponowne nawiązanie kontaktów między oboma państwami podyktowane było nie tyle wzajemną sympatią, ile koniecznością. Połączenie sił dawało możliwość faktycznego wzmocnienia ich pozycji oraz zapewnienia większej równowagi w regionie, gdyż ambicje i dążenia do dominacji zarówno Rosji, jak i Chin były hamowane przez wspólne podejmowanie działań w ramach jednej organizacji. Oba państwa miały jednak rozbieżne wizje dotyczące rozwijanej współpracy, bowiem Rosja dążyła przede wszystkim do wspólnego koordynowania polityk 
zagranicznych obu państw, podczas gdy Pekin zmierzał zwłaszcza do rozwijania współpracy gospodarczej (Bellacqua, 2010).

Wieloletni proces normalizacji stosunków rosyjsko-chińskich rozpoczął się w $1991 \mathrm{r}$ od podpisania porozumienia regulującego kwestię wschodniej części granicy rosyjsko-chińskiej (Niewiadomski, 2006). Już w 1994 r. podpisano porozumienie w sprawie zapobiegania niebezpiecznej działalności wojskowej między rządami Chin i Rosji (Yidian, 2000). W kwietniu 1996 r. Borys Jelcyn udał się z wizytą do Chin, podczas której spotkał się z Jiang Zeminem. Efektem spotkania było podpisanie aż 15 umów międzypaństwowych. Najistotniejszym dokumentem była deklaracja koncentrująca się na konieczności strategicznego partnerstwa (Mierzejewski). Jak pokazał czas, były to jedynie pierwsze kroki w rozwijającej się dalej wzajemnej kooperacji gospodarczej, politycznej, a w perspektywie być może również militarnej. Współpraca obu państw, mimo wcześniejszych napięć, była możliwa dzięki wyraźnemu odprężeniu w latach 90. Rozwiązanie spornych kwestii dotyczących granicy rosyjsko-chińskiej na mocy wspomnianego powyżej układu z 1991 r. oraz późniejszych ustaleń w zakresie demilitaryzacji granic w latach 1996 i 1997 (Wilson, 2004) stanowiło preludium do stałego rozwijania wzajemnych relacji i kontaktów między oboma państwami.

\section{CZYNNIKI SPRZYJAJĄCE WSPÓŁPRACY ROSJI I CHIN}

Mimo historycznych zaszłości oraz sporów terytorialnych Chiny i Rosja posiadają także pewne wspólne interesy. Pozwalają one na zbliżanie się obu państw i rozwijanie ich wzajemnej współpracy. Do głównych aspektów jednoczących oba państwa zaliczyć należy ich nastawienie względem Korei Północnej oraz Iranu - również zajmujących istotne miejsce w polityce zagranicznej USA. Zarówno w interesie Rosji, jak i Chin leży podtrzymanie reżimu komunistycznego w Korei Północnej - oczekiwania Stanów Zjednoczonych wobec doprowadzenia do upadku rządu komunistycznego są jednoznacznie sprzeczne z wolą Rosji i Chin, które dążą jedynie do pewnego otwarcia Korei na świat zewnętrzny, przy jednoczesnym podtrzymaniu rządów komunistycznych. Korea Północna stanowi bowiem dla nich gwarancję ograniczonych wpływów amerykańskich na Półwyspie Koreańskim (Niewiadomski, 2006). Również Iran jest miejscem konfrontacji interesów rosyjsko-chińskich z jednej i amerykańskich z drugiej strony. Zarówno Rosja, jak i Chiny jednoznacznie sprzeciwiały się dążeniom Stanów Zjednoczonych zmierzających do zahamowania irańskiego programu 
nuklearnego (Porozumienie atomowe $z$ Iranem..., 2015). Dla Chin Iran jest uznawany za jednego z kluczowych partnerów gospodarczych - w 2004 r. podpisano kontrakt wart 70 mld USD dotyczący importu ropy i gazu z Iranu oraz możliwości eksploatacji pola naftowego Yadavaran (China to develop Iran..., 2004). Dzięki polityce sankcji Zachodu wobec Iranu Chiny miały zdecydowanie większą swobodę w rozwijaniu kontaktów gospodarczych z tym państwem. Również Rosja traktuje Iran jako swojego strategicznego partnera w regionie. O bliskości tych państw świadczy najlepiej fakt posiadania statusu obserwatora w Szanghajskiej Organizacji Współpracy oraz wyraźna chęć Rosji i Chin do pełnego udziału tego państwa w strukturach organizacji. Takie rozwiązanie jest pożądane głównie ze względu na chęć ograniczenia wpływów amerykańskich na obszarze Bliskiego Wschodu. Niechęć w stosunku do USA również jest aspektem jednoczącym Rosję i Chiny.

Warto również zwrócić uwagę na aktualne dążenie do stałego rozwoju gospodarczego swoich państw - Rosja zabiega przede wszystkim o dywersyfikację własnej gospodarki, by uniezależnić budżet państwowy nadal opierający się niemalże wyłącznie na eksporcie surowców energetycznych. Chiny z kolei prowadzą politykę gospodarczą o szerokim spektrum, starając się rozwijać kolejne gałęzie przemysłu. Mają również ambicje na polu rozwijania przemysłu militarnego oraz w przestrzeni kosmicznej.

Kolejnym podobieństwem są określone tendencje odśrodkowe - oba państwa dokładają starań, by wszelkie dążenia narodowowyzwoleńcze oraz konflikty oparte na różnicach etnicznych (w przypadku Rosji były to wieloletnie walki z Czeczenami oraz dążenia separatystyczne na Kaukazie; w Chinach to głównie dążenia separatystyczne Ujgurów oraz kwestia tybetańska) były skutecznie tłumione (Wilson, 2004). Jest to zatem jeden z aspektów współpracy w ramach SOW - Deklaracja o utworzeniu Szanghajskiej Organizacji Współpracy zakłada gwarancję nieingerowania w wewnętrzne sprawy państw członkowskich, również w konflikty o charakterze etnicznym.

\section{DETERMINANTY OGRANICZAJĄCE DALSZY ROZWÓJ WSPÓŁPRACY ROSJI I CHIN}

Kolejnym aspektem, który - jak się zdaje - może sprzyjać podjęciu inicjatywy kooperacyjnej w tym regionie, jest potencjał zarówno Rosji, jak i Chin. Są to jedne z czołowych i najbardziej wpływowych państw na kontynencie azjatyckim. 
Dysponują potencjałem gospodarczym, surowcowym oraz demograficznym, co powoduje, iż posiadają one określone aspiracje w zakresie dominowania na kontynencie. Na przełomie wieków żadne z nich nie posiadało wystarczającej siły, by w pełni zdominować rywala, zatem naturalnym rozwiązaniem wydawało się połączenie sił oraz wspólne wykorzystanie własnych możliwości, by skuteczniej wpływać na środowisko międzynarodowe i kształt bezpieczeństwa w regionie. Wyraźna dysproporcja w tempie rozwoju z czasem może stać się czynnikiem różnicującym Rosję i Chiny, które zaczynają dominować i przewyższać potencjałem Rosję.

Rosja jest w pełni świadoma znacznych możliwości rozwojowych Chin, podczas gdy ona sama boryka się z problemami przestarzałej infrastruktury przemysłowej, sprzętu wojskowego, czy wreszcie w związku z wydarzeniami na Ukrainie i aneksją Krymu, negatywnym nastawieniem demokratycznej części świata. Sankcje nałożone na Rosję po wspomnianej aneksji znacząco uderzyły w kondycję gospodarki i jej budżet. Kontakty gospodarcze rozwijane w ramach SOW mogą być zatem narzędziem minimalizowania tych strat oraz systematycznego odbudowywania własnej pozycji nie tylko międzynarodowej, ale również w regionie azjatyckim. Z kolei w przypadku coraz silniejszych Chin rosnący potencjał może z czasem stanowić istotny czynnik ograniczający chęć do dalszej współpracy z Rosją. Z czasem potęga Chin może okazać się wystarczająca, by zdominować kontynent azjatycki bez konieczności wsparcia ze strony innych państw regionu.

Innym aspektem utrudniającym współpracę są wyraźnie dominujące aspiracje mocarstwowe Rosji. Wzajemne relacje z Chinami często są utrudniane i przyjmują antagonistyczny charakter ze względu na brak akceptacji przynajmniej równorzędnej pozycji Chin na kontynencie azjatyckim - widoczne jest to zwłaszcza na płaszczyźnie polityki energetycznej, gdzie dominacja Rosji była usankcjonowania niemalże historycznie (zob. dalsza część artykułu). Z kolei Chiny dążą do jak największej dywersyfikacji swoich sojuszników i partnerów handlowych. Nie opierają się zatem wyłącznie na współpracy z Rosją czy też w ramach SOW, ale utrzymują liczne kontakty dwustronne zapewniające im stopniowe poszerzanie swoich wpływów oraz wzmacnianie własnej pozycji i jednoczesne uniezależnianie się od rosyjskiej broni czy surowców energetycznych. 


\section{WSPÓŁPRACA DWUSTRONNA W ZAKRESIE HANDLU BRONIA I ENERGETYKI}

Strategiczna współpraca zapoczątkowana między Federacją Rosyjską a Chińską Republiką Ludową w 1996 r. okazała się jedynie preludium do dalszego rozwijania kontaktów między tymi państwami. W pierwszej dekadzie XXI wieku kooperacja przyjęła głównie formę współpracy gospodarczej i kulturowej, które stały się filarami tworzącej się Szanghajskiej Organizacji Współpracy. Jednak gros kontaktów chińsko-rosyjskich odbywa się również poza strukturami tej organizacji, szczególnie zaś w zakresie współpracy w obszarze energetyki oraz handlu bronią.

\section{HANDEL BRONIA}

Sprzedaż rosyjskiej broni do Chin stała się poniekąd motorem dalszego rozwijania współpracy obu państw, a bezpośrednią przyczyną było nałożenie embarga po wydarzeniach na Placu Tienanmen przez Stany Zjednoczone i państwa europejskie na handel bronią z Chińską Republiką Ludową (Bellacqua, 2010). Można zatem powiedzieć, iż to Zachód sam zachęcił Rosję i Chiny do nawiązania bliższych kontaktów, stwarzając im ku temu sprzyjające okoliczności. W okresie od 1997 do 2001 r. nawet 90\% zakupionej przez Chiny broni mogło pochodzić z Rosji. Zakupiono między innymi cztery łodzie podwodne klasy Kilo, dwa niszczyciele, 70 samolotów Su-27 oraz systemy rakiet przeciwlotniczych S-300 (Niewiadomski, 2006). Zakupy broni z Rosji pozwoliły Chinom w okresie dla niej przejściowym na stosunkowo szybkie i oszczędniejsze unowocześnienie własnego wojska, gdyż samodzielna produkcja takiego uzbrojenia byłaby zarówno czasochłonna, jak i kapitałochłonna. Podnoszona także jest kwestia embarga na sprzedaż europejskiej broni do Chin. Blokuje to Pekinowi dostęp do najnowocześniejszych technologii, a jednocześnie zmusza do dalszego korzystania z broni oferowanej przez Rosję. W 2009 r. zakupiono od Rosji kolejne niszczyciele klasy Sowriemiennyj oraz podpisano umowę na zakup kolejnych 12 myśliwców Su-30 (Michałek, 2010). Z czasem Chiny zaczęły kłaść większy nacisk na rozbudowę możliwości militarnych poprzez rodzimą produkcję oraz własne prace konstrukcyjne, zwłaszcza w zakresie lotnictwa oraz marynarki wojennej. Zgodnie z raportem SIPRI nt. rynku broni w latach 2011-2015 już zaledwie 11\% broni eksportowanej z Rosji trafiało do Chin (SIPRI). 
Rosja współuczestniczyła także w pracach nad rozwojem chińskiego programu kosmicznego oraz sektora lotnictwa cywilnego (Bellacqua, 2010). Zbliżenie się Federacji Rosyjskiej i Chińskiej Republiki Ludowej było możliwe i pożądane przez te państwa $z$ wielu względów. Przede wszystkim oba państwa były w pewnym stopniu kontestowane przez Zachód - w przypadku Rosji duże znaczenie miały przeszłe doświadczenia oraz brak demokratycznych rządów. Chiny uznawane były za kraj należący do grona dopiero rozwijających się, które mimo dynamicznej gospodarki również nie posiadało demokratycznego rządu, przestrzegającego praw człowieka oraz respektującego majątkowe prawa autorskie czy własności intelektualnej. Wobec intensywnych działań integracyjnych na Zachodzie, sprzyjających rozwojowi państw europejskich pod względem gospodarczym, niemożności swobodnego nawiązania kontaktów handlowych Chin z Europą i czerpania korzyści z tego procesu, nie dziwi poszukiwanie innych dróg dla rozwoju oraz zabezpieczenia własnych interesów przez oba państwa.

Po upadku Związku Radzieckiego zwraca się uwagę na przełamanie barier psychologicznych związanych ze współpracą, zwłaszcza gospodarczą, Rosji i Chin. Rosja, obawiając się zbytniego wzmocnienia Chin, a także zbyt licznego napływu ludności chińskiej na obszary rosyjskiego Dalekiego Wschodu i utraty dominacji na tym obszarze, długo broniła się przed zacieśnianiem kontaktów handlowych. Jednak w okresie rządów Władimira Putina poczyniono wiele kroków zmierzających do rozwijania wzajemnych relacji (Gozman, 2010). Tylko w roku 2005 wymiana handlowa między Rosją a Chinami wzrosła o ponad 37\% i wyniosła blisko 30 mld USD (Exploiting new fields..., 2006). Niewątpliwie katalizatorem takiego wzrostu był podpisany w $2001 \mathrm{r}$. Układ o Dobrym Sąsiedztwie, Przyjaźni i Współpracy, który stworzył fundamenty dla wzajemnych kontaktów gospodarczych. Mimo wszystko Chińska Republika Ludowa ewidentnie nie opiera swojej zewnętrznej aktywności gospodarczej jedynie na Rosji czy też ogólnej współpracy w ramach SOW, ale zmierza w kierunku niezależnie podejmowanej współpracy z innymi państwami kontynentu na podstawie umów dwustronnych (Hall, 2009). Świadczy o tym choćby fakt, iż w 2005 r. Rosja była dla ChRL dopiero $8 \mathrm{w}$ kolejności partnerem handlowym, podczas gdy ChRL dla Rosji drugim (Niewiadomski, 2006). Trendy te zdają się potwierdzać jedne z najnowszych doniesień - zgodnie z danymi z listopada 2015 r. zarówno eksport z Rosji do Chin, jak i odwrotnie znacząco zmalał w stosunku do roku 2014. Obroty rosyjsko-chińskie były niższe aż o 29,1\% (Duży spadek wymiany..., 2015). 


\section{WSPÓŁPRACA W ZAKRESIE ENERGETYKI}

Kolejnym aspektem są wspólne działania z zakresu energetyki. Obszar Eurazji jest niezwykle istotny ze względu na bogate złoża surowców energetycznych. Zgodnie z danymi zawartymi w Statystycznym Raporcie BP z 2004 r. 5 państw przybrzeżnych w regionie Kaspijskim posiada niemalże 19\% światowych i zlokalizowanych zasobów ropy oraz 45\% zidentyfikowanych rezerw gazu (Marketos, 2009). W produkcji ropy w regionie zdecydowanie dominuje Kazachstan, którego zasoby w 2014 r. szacowano na $30 \mathrm{mln}$ baryłek. Z kolei Turkmenistan dysponuje największymi zasobami gazu ziemnego ocenianymi na blisko 3 bln $\mathrm{m}^{3}$ (BP Statistical Review, 2015). Stąd jest to teren rywalizacji nie tylko Rosji i Chin, ale także zainteresowania Stanów Zjednoczonych i państw Unii Europejskiej, których dostawy surowców energetycznych zapewniane są z regionu Morza Kaspijskiego za pośrednictwem rosyjskiej infrastruktury przesyłowej.

Współpraca rosyjsko-chińska na płaszczyźnie energetycznej ma niezwykłe znaczenie dla wzajemnych relacji tych państw. Rosjanie odgrywali istotną rolę w rozwoju chińskiego rynku energii atomowej. W 2006 r. rosyjska firma AtomStroyExport ukończyła konstrukcje pierwszego z dwóch reaktorów jądrowych w prowincji Jiangsu (Niewiadomski, 2006). Jednak najistotniejszym aspektem wzajemnych realizacji jest komplementarność tych państw w zakresie energetyki. Rosja posiada bogate złoża ropy naftowej oraz gazu ziemnego, a także dysponuje infrastrukturą przesyłową dla surowców energetycznych. Dodatkowo Rosja na podstawie umów zawartych z Azerbejdżanem i Kazachstanem w okresie od 1998 do 2004 r. nabyła dodatkowe prawa do badania i eksploatacji dna Morza Kaspijskiego (Janusz-Pawletta, 2006). Chiny z kolei posiadają niezwykle energochłonną gospodarkę, której potrzeby zaspokajają w znacznym stopniu dzięki surowcom nabywanym od Rosji. Już w 2011 r. Chiny stały się drugim na świecie konsumentem surowców energetycznych, a w 2014 r. były państwem dominującym w zakresie importu ropy (China International Energy Data and Analysis, 2015). Szacuje się, iż do 2020 r. Chiny będą zużywać $9 \mathrm{mln}$ baryłek ropy dziennie, z czego 70\% będzie musiało pochodzić z importu (China’s Oil and Gas..., 2001). Chiny, podobnie jak w przypadku kontaktów handlowych, również w zakresie importu surowców energetycznych dążą do jak największej dywersyfikacji źródeł energii. W 2012 r. gaz naturalny importowany był głównie z Kataru (34\%), Australii (24\%), Indonezji (16\%), Malezji (13\%), Jemenu (4\%) i wreszcie Rosji (3\%). Z kolei w zakresie importu gazu za pośrednictwem rosyjskich gazociągów dochodziło do wielu konfliktów na linii Pekin-Moskwa. Już w latach 90. podjęto 
negocjacje dotyczące zbudowania gazociągu z obszaru Syberii do Chin, które przedłużały się stale ze względu na brak porozumienia w zakresie cen gazu (Tang, 2014). Dopiero w 2014 r. po dwustronnych rozmowach Putina z Xi Jinpingiem wypracowane zostało porozumienie dotyczące cen gazu dostarczanego Chinom przez Rosję (Bae, Kim, 2014). Pekin wyraźnie dąży jednak do dywersyfikowania źródeł, z których nabywane są surowce - w 2009 r. otwarto na mocy porozumienia z Uzbekistanem, Turkmenistanem i Kazachstanem gazociąg biegnący do Xinjiangu, ograniczając tym samym dotychczasowy monopol Rosji w zakresie zapewniania dostaw gazu na obszarze Azji Centralnej (Gacek, 2008).

Handel bronią i współpraca w sektorze energetycznym były i nadal są istotnymi aspektami współpracy rosyjsko-chińskiej i stanowią czynniki zbliżające je do siebie. Wspomniana powyżej coraz wyraźniejsza dysproporcja w rozwoju obu państw z czasem może zachwiać filarami aktualnie motywującymi je do współpracy. Można to już zaobserwować w polityce chińskiej, zmierzającej do jak największej dywersyfikacji kontaktów handlowych niemalże na wszystkich płaszczyznach - od handlu po politykę energetyczną. Dążenia te widać również na podstawie słabnącej wymiany handlowej z Rosją. W 2010 r. import i eksport $\mathrm{w}$ wymianie $\mathrm{z}$ Indiami wzrósł o ponad $50 \% \mathrm{w}$ porównaniu $\mathrm{z}$ rokiem poprzednim. Z Pakistanem o ponad 30\%, z Iranem o blisko 50\%. Import i eksport w wymianie z Rosją w roku 2010 zmalał o ponad 35\% (Ministerstwo Handlu Chińskiej Republiki Ludowej, 2009). Państwo środka, oraz wyraźniej dąży również do samodzielnego finansowania przez Pekin pewnych kluczowych dla Chin inwestycji czy udzielania kredytów dla państw członkowskich (Strachota, 2014).

\section{WSPÓŁPRACA W RAMACH SZANGHAJSKIEJ ORGANIZACJI WSPÓŁPRACY}

Aktualnie za jedną z istotniejszych form współpracy Rosji i Chin, obok działań dwustronnych, można uznać tę podejmowaną w ramach utworzonej w $2001 \mathrm{r}$. Szanghajskiej Organizacji Współpracy. W jej skład wchodzą obok Rosji i Chin również Kazachstan, Kirgistan, Tadżykistan oraz Uzbekistan. To właśnie przyłączenie się tego ostatniego kraju przyczyniło się do powstania organizacji, która zajęła miejsce tzw. Szanghajskiej Piątki (Melville I in., 2005, Holter, 2007). Państwami obserwatorami są Indie, Iran, Pakistan, Mongolia oraz Afganistan. Widać zatem, iż działania SOW budzą szerokie zainteresowanie na kontynencie azjatyckim. Szczególnie należy zwrócić uwagę na chęć przyłączenia się do organizacji 
Indii, Iranu i Pakistanu ze względu na potencjał (w przypadku Indii) oraz liczne kontrowersje wokół polityki prowadzonej przez te państwa (Iran i Pakistan). Dodatkowo włączenie w struktury SOW wymienionych powyżej państw będzie stanowiło o znaczącym wzmocnieniu tej organizacji oraz włączeniu istotnych ze strategicznego punktu widzenia obszarów. Szczególnie Indie wzbudzają duże emocje wśród państw europejskich, głównie ze względu na historyczne uwarunkowania i długą tradycję kolonializmu brytyjskiego w tym państwie.

Jako główne motywy stworzenia organizacji wskazuje się dążenie do dbałości o dobre relacje międzypaństwowe w regionie, rozwijanie współpracy w zakresie bezpieczeństwa, kultury, techniki, nauki, transportu, energii, środowiska i gospodarki (SCO, 2001), poszanowania równości wszystkich państw członkowskich oraz zasadę nieingerowania $\mathrm{w}$ wewnętrzne sprawy poszczególnych państw (SCO, 2001). Szczególnie ostatni aspekt jest interesujący i nawiązuje do wspomnianych powyżej dążeń separatystycznych, zwłaszcza w Rosji i Chinach. Zapis ten gwarantuje, iż przypadki często krwawego tłumienia wystąpień separatystów pozostaną zignorowane przez państwa regionu. Wraz z przedstawieniem Konwencji poświęconej zwalczaniu terroryzmu, ekstremizmów i separatyzmów stworzono odpowiednie struktury do walki z wyżej wymienionymi zagrożeniami. Zwraca się również uwagę na fakt, iż poruszenie tej problematyki było pewnym novum na kontynencie azjatyckim, a postanowienia zawarte w Konwencji były pierwszym odniesieniem do problematyki zwalczania terroryzmu w XXI wieku (Guang, 2009). Szanghajska Organizacja Współpracy niesie ze sobą jednak głębsze znaczenie niż sama współpraca kulturalna, naukowa czy w zakresie gospodarki. Od momentu zakończenia zimnej wojny zarówno Rosja, jak i Chiny dążą do ograniczania amerykańskich wpływów na kontynencie amerykańskim. Chińska strategia opiera się zatem głównie na budowie silnego systemu multilateralnych stosunków międzypaństwowych w regionie, który pozwoli na wzmocnienie kolektywnej siły państw regionu (Wu, Lansdowne, 2008).

W początkowej fazie funkcjonowania Organizacji - zaraz po jej utworzeniu, szczególnie podkreślano aspekty integracji i kooperacji gospodarczej i kulturowej jako gwaranta rozwoju i stabilności regionu oraz podstawy szerszej współpracy politycznej i w zakresie bezpieczeństwa (SCO, 2004). W 2006 r. podczas spotkania w Szanghaju ustalono zagadnienia energetyczne, transportu i technologii informacyjnych jako priorytetowe (SCO, 2006). W zakresie zwalczania zagrożenia terroryzmem podkreślano zwłaszcza konieczność podjęcia działań, między innymi w poniższych sferach: 
1. Zapewnienie współpracy odpowiednich służb dyplomatycznych, władz ustawodawczych, służb specjalnych oraz służb odpowiedzialnych za obronę narodową.

2. Stworzenie odpowiedniej infrastruktury zwalczającej zagrożenia dla pokoju, stabilizacji i bezpieczeństwa $\mathrm{w}$ regionie.

3. Koordynowanie ustawodawstwa w zakresie bezpieczeństwa.

4. Współpraca w zakresie opracowywania nowych technologii służących konstruowaniu broni adekwatnej do zwalczania nowych zagrożeń i wyzwań dla bezpieczeństwa w regionie.

5. Zwalczanie nielegalnego przemytu broni, amunicji, środków wybuchowych, narkotyków, zwalczanie zorganizowanej przestępczości międzynarodowej i nielegalnej imigracji.

6. Zwalczanie cyberterroryzmu (Guang, 2009).

$\mathrm{Na}$ tym etapie nie pojawiała się jeszcze idea współpracy militarnej, choć już samo powstanie organizacji $\mathrm{w}$ tak istotnym strategicznie regionie wzbudziło zaniepokojenie zwłaszcza Stanów Zjednoczonych, które miały własne silne wpływy na tym obszarze - między innymi wojska stacjonujące w Afganistanie oraz bazy wojskowe w Uzbekistanie (Jagielski, 2005) i Kirgistanie (Lang, 2013). Rosja poprzez stworzenie Szanghajskiej Organizacji Współpracy zmierzała stopniowo nie tylko do zacieśnienia kooperacji z Chinami i tym samym zapewnienia sobie pewnej kontroli nad działaniami wcześniejszego rywala, ale również do stopniowego wyparcia sił amerykańskich z jej historycznego już obszaru żywotnych interesów, co było wielokrotnie podkreślane. Wydaje się zatem, iż Rosja jest tym państwem członkowskim, któremu najbardziej będzie zależało na wzmacnianiu aspektu współpracy militarnej w ramach SOW. Chiny, choć angażują się w organizowane manewry i ćwiczenia wojskowe, zdecydowanie bardziej skupiają swoje działania na aspektach gospodarczych (Malik, 2010).

Obok współpracy gospodarczej coraz istotniejsze miejsce w funkcjonowaniu organizacji zajmują kwestie energetyczne, które poruszane są na forum od $2006 \mathrm{r}$. Taka ewolucja nie jest zaskoczeniem, bowiem SOW skupia w swoich strukturach obszary o bogatych zasobach ropy i gazu i jednoczy jednych z największych światowych producentów surowców energetycznych (Rosja, Iran jako państwo obserwator i Kazachstan) oraz największych konsumentów surowców energetycznych (Chiny i Indie, podobnie jak Iran, w charakterze obserwatora). Od 2007 r. w ramach SOW działa forum zmierzające do tworzenia jednolitych ram polityki energetycznej państw wchodzących w skład organizacji (Malik, 2010).Współpraca ta nie jest jednak łatwa, głównie ze względu na wspomnianą 
powyżej politykę Pekinu zmierzającą do dywersyfikacji zaopatrzenia w surowce energetyczny, i zapewnienia sobie tym samym większej niezależności od dążącej do dominacji na tej płaszczyźnie Rosji.

Powyższe informacje pokazują ewolucję organizacji od luźnego i niesformalizowanego forum dyskusyjnego, w kierunku coraz wyraźniejszej instytucjonalizacji organizacji. Choć istnieje wiele czynników różnicujących dwóch najsilniejszych członków, a współpraca na kontynencie azjatyckim przybiera nierzadko formę kontaktów dwustronnych poza SOW, to widać, iż zakres działania tej organizacji ulega poszerzaniu. Obok kontaktów kulturowych, wspólnej walki z terroryzmem i separatyzmami rozwija się stale współpraca handlowa, energetyczna i militarna. Organizacja podlega także większej instytucjonalizacji - w rok po utworzeniu organizacji powstały dokumenty określające ramy współpracy w zakresie zwalczania terroryzmu, od 2004 r. działa stały sekretariat (Wang, 2008).

\section{PRZYSZŁOŚĆ WSPÓŁPRACY W RAMACH SZANGHAJSKIEJ ORGANIZACJI WSPÓŁPRACY - ZAGROŻENIE DLA ZACHODU?}

Jednym z priorytetów Szanghajskiej Organizacji Współpracy jest dążenie do zapewnienia bezpieczeństwa regionalnego. W związku z tym coraz częściej pojawia się pytanie o możliwą w przyszłości współpracę na polu militarnym. Trudno jest zignorować potencjał tej organizacji, skupia ona bowiem obszar ponad trzech czwartych Eurazji, a jej obszar zamieszkuje 1/4 populacji całego globu. Dodatkowo żywo zainteresowane organizacją są kolejne państwa. Jaka jest zatem przyszłość organizacji i czy pogłębiające się dysproporcje w potędze dwóch najistotniejszych członków SOW będą wpływać negatywnie na dalsze działania organizacji?

Choć formalnie Szanghajska Organizacja Współpracy nie nosi znamion organizacji o charakterze militarnym, to przeprowadzane były już liczne wspólne manewry, między innymi w ramach programu „Współpraca 2003”, oraz dwustronne manewry chińsko-rosyjskie, rosyjsko-uzbeckie i rosyjsko-indyjskie, a także ćwiczenia wojskowe w ramach programu „Misja Pokojowa 2007” (Perkowska, 2010). Pierwsze wielostronne ćwiczenia antyterrorystyczne odbyły się w 2003 r. i obejmowały dwa etapy - pierwszy, przeprowadzony w Kazachstanie, obejmujący walkę z terroryzmem, oraz drugi, w Chinach, skupiający się na operacjach uwalniania zakładników. Co ciekawe, był to pierwszy przypadek, kiedy obce 
wojska zostały wpuszczone na chińskie terytorium. Kolejne ćwiczenia wojskowe rosyjsko-chińskie odbyły się w 2005 r. w ramach SOW i obejmowały wspólne działania sił lądowych, powietrznych i morskich (Wang, 2008). Kooperacja militarna mogła wynikać z kilku aspektów. Po pierwsze, rozszerzanie NATO pod koniec lat 90. o byłe państwa satelickie Związku Radzieckiego wzbudziło pewien niepokój nie tylko Federacji Rosyjskiej, ale także Chińskiej Republiki Ludowej. Po atakach terrorystycznych w $2001 \mathrm{r}$. oraz rozpoczęciu kampanii antyterrorystycznej wzmogły się obawy o zwiększanie obecności wojsk amerykańskich na kontynencie azjatyckim. Także niestabilna sytuacja w Afganistanie i obecność wojsk amerykańskich skłaniała do rozważenia współpracy militarnej w obliczu zagrożenia destabilizacją całego regionu. W 2009 r. z inicjatywy Szanghajskiej Organizacji Współpracy zwołano konferencję reprezentantów NATO, G8, ONZ, UE i OIC (Organizacja Współpracy Islamskiej), podczas której podkreślono gotowość i chęć państw SOW do podjęcia współpracy z NATO i Stanami Zjednoczonymi, przy jednoczesnym podkreśleniu sprzeciwu wobec utrzymującej się militarnej obecności USA na kontynencie azjatyckim (Walberg, 2009).

Takie nastawienie względem USA stale się utrzymuje. Podczas szczytu w 2014 r. w Duszanbe podkreślono konieczność dalszego rozwijania współpracy w zakresie zapewniania bezpieczeństwa w regionie oraz eliminowania militarnej obecności amerykańskiej. Amerykanie zostali między innymi skrytykowani za ich politykę względem Syrii i Iranu (Strachota, 2014). Stanowisko państw należących do SOW może sugerować, iż w celu wyeliminowania amerykańskiej obecności w ich regionie podejmowane będą dalsze, wspólne działania o charakterze militarnym.

Kolejnym testem dla bliskości sojuszu chińsko-rosyjskiego oraz przyszłości potencjalnej współpracy militarnej w ramach SOW okazała się aneksja Krymu. Pekin nadal przywiązuje duże znaczenie do współpracy z Rosją, a ta w świetle aktualnej izolacji przez Zachód w związku z aneksją Krymu w 2014 r. siłą rzeczy szuka bliższych kontaktów z Chinami. Reakcja Chin na aneksję Krymu nie była jednoznaczna. W oświadczeniu chińskiego Ministerstwa Spraw Zagranicznych ChRL podkreślono, iż Chiny respektują niepodległość, suwerenność i integralność terytorialną Ukrainy, niemniej jednak nie skrytykowano otwarcie i jednoznacznie działań Federacji Rosyjskiej (Gruszka, 2014). Taka reakcja Chin nie powinna być zaskoczeniem, bowiem działania Federacji Rosyjskiej dotyczyły obszaru poza żywotnymi interesami Pekinu, a współpraca z Rosją na kontynencie azjatyckim nadal odgrywa istotną rolę w polityce zagranicznej i bezpieczeństwa tego państwa. Ponadto to Rosja, a nie Ukraina jest istotniejszym partnerem 
handlowym. Wymiana handlowa z Ukrainą jest kilkakrotnie niższa niż z Rosją (odpowiednio ok. 11 mld UDS i 87 mld USD) (Kaliński, 2014). Jeszcze w 2014 r. Putin udał się z wizytą do Chin, gdzie Gazprom podpisał kontrakt na rekordową sumę 400 mld dolarów. Również na płaszczyźnie militarnej współpraca nadal się rozwija. W maju 2015 r. zorganizowano po raz pierwszy wspólne manewry na Morzu Śródziemnym (Kruczkowska, 2015) i choć Ministerstwo Obrony Chin zapewniało, iż nie są to manewry wymierzone w Europę, to łatwo zauważyć, iż wspólne ćwiczenia wojskowe przypadły na okres zaostrzenia sytuacji politycznej w Europie i w kontaktach z USA. Mimo wszystko nadal trudno mówić o znamionach militarnego charakteru organizacji. Choć współpraca wojskowa nadal się rozwija, Chiny wyraźnie podkreślają swoją niechęć do zbyt nadmiernego rozszerzania aspektów militarnej współpracy. Ponadto spekulacje na temat dążenia do stworzenia z SOW przeciwwagi dla NATO wydają się mało realne, biorąc pod uwagę, iż większość państw należących do organizacji jest również zaangażowana w program Partnerstwa dla Pokoju, a także ze względu na zbyt duże rozbieżności wewnątrz organizacji odnośnie przyszłości współpracy militarnej.

\section{PODSUMOWANIE}

Wydaje się, iż wobec doświadczeń historycznych i niegdysiejszych bliskich relacji Rosji i Chin, ich dzisiejsze zbliżenie może być uznane za naturalne. Są to państwa wpływowe, silne i należą do grona głównych decydentów na kontynencie azjatyckim. Oba państwa dążą do wzmocnienia własnej pozycji w regionie oraz wykazują niechęć w stosunku do Zachodu, a także są w pewnym stopniu przez państwa zachodnie kontestowane (choć w różnym zakresie). Są to zatem czynniki sprzyjające ich zbliżaniu się. Do elementów kontrastujących z kolei należała z pewnością różnorodność priorytetów - o ile Chiny dążyły przede wszystkim do rozwoju współpracy gospodarczej w ramach organizacji, o tyle Rosja oczekiwała, iż za jej pośrednictwem uda jej się przywrócić dawne wpływy polityczne z okresu radzieckiej świetności, a także rozwijać współpracę o charakterze militarnym. Mimo istniejących barier dla kooperacji oba państwa zacieśniły własne kontakty oraz zdecydowały się na prowadzenie wspólnych działań w ramach Szanghajskiej Organizacji Współpracy, co było wynikiem realnej oceny aktualnej sytuacji międzynarodowej i dostrzeżenia szans wynikających dla nich z takiej współpracy. Pokazują one, iż hipoteza odnośnie pragmatycznego charakteru jest prawdziwa. Liczne korzyści płynące z podjęcia wspólnych działań przeważyły antagonizmy, 
skłaniając Rosję i Chiny do nawiązania bliższej kooperacji. Druga hipoteza, zakładająca, iż SOW stanowi arenę nie tylko rozwijania kontaktów, ale również konfrontacji i rywalizacji jej dwóch najważniejszych członków, również wydaje się prawdziwa. Zmieniająca się proporcja w potędze Rosji i Chin oraz polityka Chin zakładająca dywersyfikację kontaktów handlowych i w zakresie energetyki (w celu uniezależnienia się od Rosji, ale też jej osłabienia) pokazują, iż mimo współpracy państwa te jednocześnie ze sobą rywalizują.

Zawiązanie się współpracy między Rosją a Chinami ma niezwykle istotne znaczenie dla międzynarodowego bezpieczeństwa. Są to państwa istotne z punktu widzenia Zachodu z dwóch względów - Rosja jako państwo posiadające bogate złoża surowców energetycznych jest ich praktycznie jedynym dostawcą w Europie. Chiny z kolei są państwem cieszącym się szybkim wzrostem gospodarczym, a także zmierzającym systematycznie do rozwoju w kolejnych dziedzinach. Oba te państwa odgrywają zatem istotną rolę w regionie Eurazjatyckim, a nawet w nim dominują. Wszelkie formy współpracy zmierzające do wzmocnienia pozycji tych państw na tak strategicznym obszarze są postrzegane zwłaszcza przez Stany Zjednoczone jako potencjalne zagrożenie. Dowodem na to może być fakt wyraźnego zwrócenia się Stanów Zjednoczonych w kierunku obszaru Azji i Pacyfiku. Dwie ostatnie strategie bezpieczeństwa tego mocarstwa podkreślają wagę tego obszaru, jego strategiczne znaczenie i konieczność budowania na tym obszarze skutecznej przeciwwagi dla rosnącego znaczenia ChRL oraz dążeń Federacji Rosyjskiej do powrotu jej niegdysiejszej mocarstwowości.

Wobec strategicznego znaczenia obszaru Eurazji szczególne zaniepokojenie budzi widoczny powrót do ekspansjonistycznej polityki Rosji. Jednak izolowanie Rosji na arenie międzynarodowej może być czynnikiem w naturalny sposób popychającym Rosję w kierunku Pekinu i tym samym wzmacniającym tendencje współpracy między tymi państwami. Z drugiej strony pozycja Rosji jest aktualnie osłabiona (nadal posiada znaczące zasoby oraz potencjał, jednak w wielu przypadkach nie wykorzystuje ich efektywnie), a Chiny stale wzmacniają swój potencjał i potęgę. Działania podejmowane w ramach Szanghajskiej Organizacji Współpracy mogą być postrzegane przez Zachód również w kategoriach pozytywnych jako pewne ograniczenie dla Rosji i Chin, nadawanie pewnych ram współpracy oraz gwarantowanie większej stabilności w regionie. Wydaje się zatem, iż SOW daje Rosji i Chinom zarówno narzędzie wzmacniania ich pozycji, a z drugiej strony hamuje ambicje dominacji obu państw.

Najistotniejszym aspektem bliskich kontaktów Rosji i Chin, zwłaszcza na płaszczyźnie współpracy w ramach Szanghajskiej Organizacji Współpracy, jest 
możliwość stworzenia również sojuszu militarnego. Już teraz istnieje ryzyko, iż SOW w przypadku rozwoju w przyszłości również szerszej współpracy militarnej, która przybrałaby postać sformalizowaną, może okazać się siłą równoważącą NATO i konkurującą z wpływami amerykańskimi na kontynencie azjatyckim. Faktem jest, iż już w ostatnich latach, od momentu utworzenia SOW, organizowane były cykliczne manewry oraz ćwiczenia wojskowe państw wchodzących w skład organizacji. Współpraca ta jest kontynuowana, przybiera nowe formy i nie odnosi się już jedynie do aspektów zwalczania zagrożenia terroryzmem czy handlu bronią. Ulega także pewnej instytucjonalizacji. Trudno jednak nadal mówić o militarnym charakterze organizacji, a tym bardziej możliwości konkurowania z NATO. Część państw SOW jest formalnie związana z NATO za pośrednictwem programu Partnerstwo dla Pokoju, a same państwa członkowskie nie dysponują (przynajmniej na chwilę obecną) potencjałem dorównującym NATO. Kolejnym utrudnieniem dla dalszego rozwijania struktur militarnej współpracy jest pewna niechęć Chin, które mimo wszystko nadal skupiają się głównie na aspektach gospodarczych oraz zagadnieniach z zakresu energetyki.

\section{BIBLIOGRAFIA:}

Bae, J-H., Kim, J-H (red.). (2014). China's Strategic Envirnoment and External Relations in the Transition Period. Korean Institute for National Unification: Jinwood Choi.

BBC (01.11.2004). China to Develop Iran Oil Field. Pobrane z: http://news.bbc.co.uk/2/ hi/business/3970855.stm.

Bellacqua, A. (2010). Introduction. W: J. Bellacqua (red.), The Future of China-Russia Relations (1-13). Lexington: University Press of Kentucky.

BP Statistical Review of World Energy, Oil (2015). Pobrane z: https://www.bp.com/ content/dam/bp/pdf/energy-economics/statistical-review-2015/bp-statisticalreview-of-world-energy-2015-full-report.pdf.

Declaration on the Establishment of the Shanghai Cooperation Organization (2001). Shanghai.

Gacek, Ł (2008). Chiny-Rosja: strategiczne partnerstwo czy nieunikniony konflikt? Wybrane aspekty kształtowania się relacji wzajemnych. W: J. Marszałek-Kawa (red.), Chińska polityka zagranicznai jej uwarunkowania. Toruń: Wydawnictwo Adam Marszałek.

Gozman, G. (2010). The Sino-Russian Strategic Partnership: How Close? Where To?. W: J. Bellacqua (red.), The Future of China-Russia Relation. Lexington: University Press of Kentucky.

Gruszka, P. (2014). Nie może być Wielkiej Rosji i Wielkich Chin. Pobrane z: http://wiadomosci.onet.pl/swiat/radoslaw-pyffel-nie-moze-byc-wielkiej-rosji-i-wielkich-chin/ qs6vt. 
Guang, P. (2009). The SCO's Success in Security Architecture. W: R. Hisken (red), The Architecture of Security in the Asia-Pacific. Canberra: ANU E PRESS.

Hall, M. (2009). The Shanghai Cooperation Organisation: A Partner for Stabilizing Afghanistan?. Center for Defence and StrategicStudies.

Holter, D. (2007). The Shanghai Cooperation Organisation: Implications for Japanese Foreign and Security Policy. Wiedeń: Webster University.

International energy data and analysis (2015). Pobrane $\mathrm{z}$ : http://www.eia.gov/beta/ international/analysis.cfm? iso $=\mathrm{CHN}$.

Jagielski, W. (2005). Uzbekistan wyprasza USA z ich bazy wojskowej. Pobrane z: http:// wiadomosci.gazeta.pl/wiadomosci/1,114881,2848640.html.

Janusz-Pawletta, B. (2006). Zasoby Morza Kaspijskiego. Wydobycie i transport do Europy. Aspekt prawno-międzynarodowy. Bezpieczeństwo Narodowe, 1-2006 (1), 74-80.

Joint Communique of the Meeting of the Council of Heads of Member States of the Shanghai Cooperation (2006). Shanghai. Pobrane z: http://www.sectsco.org/EN123/ show.asp?id=95.

Kaczmarski, M. (2015). Russia-China Relations in the Post-War Crisis International Order. Oxon: Routledge.

Kakar, M. (1995). Afghanistan: The Soviet Invasion and the Afghan Response 1979-1982. Berkeley: University of California Press.

Kaliński, A. (2014). Chiny bardziej za Rosja niż za Ukraina. Pobrane z: http://www. obserwatorfinansowy.pl/warto-przeczytac/chiny-bardziej-za-rosja-niz-za-ukraina/.

Kowalski, B. (2012). Trzeci front - złożenia, przebieg i konsekwencje. W: M. Pietrasiak, W. Dacyszen (red.), Chiny w stosunkach międzynarodowych (195-205). Łódź: Wydawnictwo Naukowe Ibidem.

Kruczkowska, M. (2015). Chiny buduja sojusz wojskowy z Rosją. Pobrane z: http:// wyborcza.pl/1,75477,17885785,Chiny_buduja_sojusz_wojskowy_z_Rosja.html.

Lang, J. (2013). Kirgistan wypowiada USA umowę o bazie Manas. Pobrane z: http://www. osw.waw.pl/pl/publikacje/analizy/2013-07-10/kirgistan-wypowiada-usa-umowe-o-bazie-manas.

Lawrence, A. (1998). China under Communism. Londyn: Routledge.

Malik, M. (2010). The Shanghai Cooperation Organization. W: S. Ganguly i in. (red.), Handbook of Asian Security Studies. Oxon: Routledge.

Marketos, T. N. (2009), China's Energy Geopolitics: the Shanghai Cooperation Organisation and Central Asia. Oxon: Routledge.

Melville, A. i in. (2005). Russian Foreign Policy in Transition. Concepts and realities. Budapeszt: Central European University Press.

Michałek, M. (2010). Chiny - dynamiczny rozwój militarnej potęgi. Portal Spraw Zagranicznych.

Mierzejewski, D. Szanghajska Organizacja Współpracy. Regionalizm środkowoazjatycki. Materiały nieopublikowane. Pobrane z: http://mierzejewski1290.republika.pl/ teksty/sow.pdf. 
Ministerstwo Handlu Chińskiej Republiki Ludowej. Pobrane z: http://english.mofcom. gov.cn/article/statistic/lanmubb/chinaeuropeancountry/201001/20100106727951. shtml.

Ministerstwo Handlu chińskiej Republiki Ludowej. Pobrane z: http://english.mofcom. gov.cn/article/statistic/lanmubb/ASEAN/201005/20100506934001.shtml.

Nie będzie nowych baz USA w Uzbekistanie. Pentagon dementuje rosyjskie informacje (2014). Pobrane z: http://www.defence24.pl/111876,nie-bedzie-nowych-baz-usaw-uzbekistanie-pentagon-dementuje-rosyjskie-informacje.

Niewiadomski, Ł. (2006). Stosunki chińsko-rosyjskie i ich wpływ na świat. Bezpieczeństwo Narodowe, 1-2006 (1), 143-156.

People's Daily Online (2006). Exploiting New Fields for China-Russian Trade. Pobrane Z: http://en.people.cn/200603/27/eng20060327_253815.html.

Perkowska, A. (2010). Szanghajska Organizacja - geopolityka. Economy and Management (3/2010). Pobrane z: file://C:/Users/Anna\%20Kobierecka/Downloads/ httpwww_zneiz_pb_edu_plkwartalnik320101_5perkowska\%20(2).pdf.

Pietrasiak, M., Dacyszen, W. (2012). Regionalny aspekt historii stosunków rosyjsko-chińskich. Łódź: Wydawmoctwo Naukowe Ibidem.

Roberts, J. (2003). The origins of conflict in Afghanistan. Westport: Praeger.

Roszkowski, W. (2005). Półwiecze. Historia Polityczna Świata po 1945 roku. Warszawa: Wydawnictwo Naukowe PWN.

Strachota, K. (2014). Szczyt Szanghajskiej Organizacji Współpracy - o azjatycki „koncert mocarstw. Pobrane z: http://www.osw.waw.pl/pl/publikacje/analizy/2014-09-17/ szczyt-szanghajskiej-organizacji-wspolpracy-o-azjatycki-koncert.

Tang, T. (2014). China's Natural Gas Imports and Prospects. Prepared for: Dr. Yufeng Yang, Energy Research Institute, National Development and Reform Commission. Duke University.

The Tashkent Declaration from the Shanghai Cooperation Organization Summit in Tashkent. (2004). Uzbekistan. Pobrane z: http://xn----jtbhwghdp7a.xn--plai/data/ resources/Tashkent_Declaration_\%20July\%2017_\%202004.pdf.

TVN, Porozumienie atomowe z Iranem. Raport specjalny. Pobrane z: http://www.tvn24. $\mathrm{pl} /$ raporty/porozumienie-atomowe-z-iranem,908.

Walberg, E. (2009). Diplomacy: Russia and China confront the U.S. and NATO over Afghanistan. Global Research. Pobrane z: http://www.globalresearch.ca/index. php? context=va\&aid $=13291$.

Wilson, J. (2004). Strategic Partners: Russian-Chinese Relations in the Post-Soviet Era. Oxon: Routledge.

Wu, G., Lansdowne, H. (2008). International multilateralism with Chinese characteristics. Attitude Changes, Policy Imperatives, and Regional Impacts. W: G. Wu (red.), China Turns to Multilaterailsm. Foreign Policy and Regional Security. Oxon: Rout; edge.

Yidian, Z. (2000). Chińska dyplomacja - słownik. Pekin. 